\title{
Critical Study of Leadership Styles in Handling COVID-19 Crisis
}

\author{
Richa Nangia ${ }^{1}$ and Richa Arora ${ }^{2}$
}

\begin{abstract}
The world is passing through an unparalleled crisis, named Covid-19. The world economy is surrounded by it, and therefore on a daily basis, there are many updates in the situation, which is rapidly changing the status of the nation's worldwide. Some are on the verge of survival, some are trying to get the makeover and some are facing turmoil. In order to overcome this situation, the leaders of the different countries had to plan the strategies to deal with this current situation. Therefore, this paper is focused upon determining the different leadership styles followed by the leaders of the different countries and the effectiveness of these leadership styles in handling the Covid-19 situation. Both primary and secondary data has been collected for the research. This research would encourage the academicians, researchers, management students, corporate managers and employees etc. to understand the impact of different leadership styles followed by the leaders to control any devastating situation that could shatter the economy of any nation. This research would help develop the proper understanding of the different leadership styles and its implementation for determining the effectiveness of the different leadership styles in handling this uncontrollable situation.
\end{abstract}

Keywords: Leadership; COVID-19 crisis; citizen's reaction; countries

\section{Introduction}

Leadership is a kind of power where one person has the ability to influence or change the values, beliefs, behaviour and attitudes of another person (Ganta, and Manukonda, 2014). A person with strong leadership ability will be a good example or role model to their employees, because the leader who is able to effectively achieve some good result or achievement gains the trust and admiration of their employees, and inadvertently changes their values, beliefs, behaviour and attitudes, for mimicry is the sincerest form of flattery (Grint, 2007).

An effective leader is a first and foremost condition for success. The phenomenally successful leaders adopt a combination of multiple leadership styles or just one selective style. Leadership style is the manner and approach of providing direction, implementing plans, and motivating people. As seen by the employees, it includes the total pattern of explicit and implicit actions performed by their leader (Newstrom, Davis, 1993). Mentioned below are the different styles that a leader follows:-

Authoritarian or Autocratic - the leader tells his or her employees what to do and how to do it, without getting their advice (U.S. Army, 1973).

Delegative or Laissez-Fair (Free-Rein) - the leader allows the employees to make the decisions, however, the leader is still responsible for the decisions that are made. (U.S. Army, 1973).

\footnotetext{
${ }^{1}$ Richa Nangia, K.R. Mangalam University, India. E-mail: richa.nangia16@gmail.com.

${ }^{2}$ Richa Arora, K.R. Mangalam University, India. E-mail: ric.arora85@gmail.com.
} 
Participative or Democratic - the leader includes one or more employees in the decision making process, but the leader normally maintains the final decision making authority (U.S. Army, 1973).

As we all are aware about the corona virus (COVID-19), the Virus that originated in China's Wuhan has killed more than 110,000 people and infected 1.79 million. The corona virus is a family of viruses that can cause a range of illnesses in humans including common cold and more severe forms like SARS and MERS which are life-threatening. The virus is named after its shape which takes the form of a crown with protrusions around it and hence is known as corona virus.

The pandemic is the defining global health crisis of our time and the greatest challenge we have faced. Countries are doing their best to slow the spread of the virus by testing and isolating patients to prevent further spread, cancelling travels, quarantining citizens, preventing gatherings and even complete lockdowns in most of the countries but COVID-19 is much more than a health crisis, it has the potential to create devastating social economic and political crisis that leaves deep scars (WHO, 2020).

As we all know about the Corona virus outbreak that is affecting the entire globe and has taken lives of so many people and also affected the global economy; the countries may not have the leaders they idealise, but the corona virus pandemic has certainly revealed what kind of leader they've got.

Even after months of the virus outbreak there is no single vaccine or a single medicine to cure the virus. When we all are in such a situation than we all look for the hope and then the leaders come forward with different ideas and solutions for the situation. In this paper the aim will be to cover the different leadership styles that are followed by the leaders of different countries and how the citizens reacted to the leader's decisions around the globe to fight against corona virus.

Leadership in a crisis: Responding to the corona virus outbreak and future challenges, the corona virus pandemic has placed extraordinary demands on leaders in business and beyond. The humanitarian toll taken by COVID-19 creates fear among employees and other stakeholders. Indeed, the outbreak has the hallmarks of a "landscape scale" crisis: an unexpected event or sequence of events of enormous scale and overwhelming speed, resulting in a high degree of uncertainty that gives rise to disorientation, a feeling of lost control, and strong emotional disturbance. Once leaders recognise a crisis as such, they can begin to mount a response. But they cannot respond as they would in a routine emergency, by following plans that had been drawn up in advance. During a crisis, which is ruled by unfamiliarity and uncertainty, effective responses are largely improvised. (D'Auria and Smet, 2020)

\section{Literature Review}

Observer Research Foundation (2020) discussed that India's Prime Minister Narendra Modi use a charismatic leadership style to handle this corona crisis. PM Narendra Modi addresses the nation regarding coronavirus and its public receptivity has been largely positive. He assures that government is doing its best. He also gave people a sense of national purpose by bringing them together for the 'Janta Curfew'. 
Fortune Magazine (2020) explained that USA's President Donald Trump follow autocratic leadership style for handling corona crisis. Trump sign a relief bill. This bill is estimated to cost about $\$ 100$ billion. In this bill, the president will provide various benefits to its citizens e.g. expand medical and unemployment benefits, guarantee free coronavirus testing for all, expand paid sick leave etc.

The Diplomat (2020) explained that Japan's Prime Minister Shinzo Abe follow cooperative leadership style to handle corona crisis. He decided to close the schools. His government will also provide refunds of lunch money to parents. Subsidies would be provided for those who work without regular work contracts. It is reported that the government is considering a third batch of measures to help protect people's lives and stabilize the economy.

Karamunya (2017) described that transformational leaders encourage subordinates to put in extra effort and to go beyond what they (subordinates) expected before. Transformational leaders achieve the greatest performance from subordinates since they are able to inspire their subordinates to raise their capabilities for success and develop subordinates innovative problem solving skills. As expected, relational analysis found that all transformational leadership behaviours have a strong positive correlation with organizational performance.

Podsakoff et. al (2014) explained about leadership behaviour that leadership behaviour can affect trust and satisfaction of employees to organization and organizational citizenship behaviour further enhances the relationship between leadership style and organizational commitment directly.

Babu (2011) explained that leadership styles play a pivotal role. It has been considered as a prime criterion to be successful and effective in the host country. Study has examined 25 Japanese and 23 American expats in India focusing on their leadership styles. In order to determine the leadership styles of these managers from altogether different countries, the study has investigated ten leadership components.

Sayeed and Shankar (2009) explained multivariate relationships between emotional intelligence and transformational leadership. The canonical correlation between emotional intelligence and transformational leadership dimensions revealed significant relationships, which confirmed emotional intelligence as an important element of managerial temperament.

Newstrom (2007) focuses on leadership style that leadership style is the total pattern of explicit and implicit leader's action as observed by employees. It shows a consistent, each style also reflects, implicitly or explicitly, a manager's beliefs about a subordinate's capabilities (Theory $\mathrm{X}$ or Theory Y). The way in which a leader uses power also establishes his leadership styleautocratic, democratic and participative.

Priyabhashini et. al. (2005) focuses on relationship between transformational leadership, leader's expectation from follower (Pygmalion effect) and followers' readiness for promotion using a sample of 101 managers from two organizations in India. Respondents answered questions on their readiness for promotions and on their superior transformational leadership and expectations.

Mosadeghrad (2003) explained that leadership style is based on a leader's thinking, behaviour and organizational environment. It can be viewed as a series of managerial attitudes, behaviours, characteristics and skills based on individual and organizational values, leadership interests and reliability of employees in different situations. 
Goleman (2000) explained that listing the different leadership styles and compared them with the analogy of a set of golf clubs. As a golfer would select the correct club for the appropriate shot, a competent leader would apply a particular leadership style in a certain scenario. Goleman summarized that leaders who used styles that positively affected the climate have decidedly better results than those who did not.

Hence the objectives of the study are formulated as follows: a) To study the leadership style followed by leaders of countries understudy during Corona Pandemic. b) Effectiveness of leadership styles followed by leaders of countries understudy during Corona Pandemic. c) Citizen's reaction/response towards the leader's decision.

Both primary and secondary data have been used in this study. Primary data for current study is gathered from primary sources which includes interviews and survey of citizens of countries under study. A random sample of 6 countries (India, North Korea, Spain, Japan, USA, China) was selected and informal interviews were conducted targeting 50 citizens from each country with the help of reviews of the relevant literature. Secondary data was mainly sourced from business journals, newspapers, magazines, periodicals, websites and so on.

\section{Findings}

\section{INDIA}

\section{Leadership Style followed in India during Corona Crisis}

Indian Prime Minister Mr. Narendra Modi followed the Democratic Leadership Style. The Indian leader is trying to do two difficult tasks at once: positioning India as a leader in crafting global responses to the corona virus even while attempting to fight it at home.

Mr Modi called the SAARC (South Asian Associate for Regional Cooperation) videoconference on $15^{\text {th }}$ March in which all SAARC countries participated. Mr Modi asked for a rapid response team of medical workforce and announced an initial contribution of $\$ 10$ million for a new corona virus emergency fund.

After that on 17th March, Mr Modi contacted Saudi Crown Prince Mohammed Bin Salman, the current G-20 chair, to propose the possibility of replicating the SAARC videoconference, this time only with the G-20 leadership. The online G-20 session took place on $26^{\text {th }}$ March.

India suffers from poor public health infrastructure and is overpopulated, which makes social distancing difficult to impose. On 22 ${ }^{\text {nd }}$ March, Mr Modi declared that 75 districts in India comprising some of the highly populated and hard-hit areas - would undergo lockdown. On $23^{\text {rd }}$ March, New Delhi announced that domestic airlines would be grounded. And then, on $24^{\text {th }}$ March, Mr Modi announced a 3 week, nationwide lockdown, a bold step meant to control the spreading of the corona virus but also a step that will prove extremely difficult to enforce in a nation of 1.3 billion people. Whether India comes out of the corona virus crisis without a misery would be determined, by the actions of one man - Prime Minister Narendra Modi.

\section{Effectiveness of Mr. Narendra Modi's Leadership during COVID-19 Crisis}

Mr Modi has been communicating with Indians on regular basis from the very beginning and has not been shy of expressing that this pandemic would require global help and assistance. Comparing this to the disorganized performance of other countries like Europe in managing 
this crisis within its boundaries or that of with the US President Donald Trump who has been all over the places in his attempt to come to have control over this tragedy or the Chinese leadership whose irresponsible behaviour led to the crisis throughout the globe and one can evaluate how effective Modi's leadership has been to control this pandemic. Asking public to clap and beat thalis before most of India went on lockdown was also the first of the many ideas of leadership that have clearly originated during this historic crisis. The idea is that any response to a crisis must begin with communication but not just any communication, though communication that has a cultural context. This brings me to the final lesson of leadership from the Corona pandemic - the art of taking risk and challenging decisions. This is exemplified by the announcement of Mr Modi that the country will go into a 21-day lockdown. This is the biggest ever quarantine in history, and challenging in a country where movement of goods and services face difficulty even in normal circumstances and where most public are involved in informal jobs.

But this is not only necessary, it our top-priority. Such sensational measures are needed if the corona virus is to be controlled. In a sense India is doing what even developed nations like America is failing to do. European countries such as Italy, France and the UK, which agitated on enforcing restrictions and lockdowns at the earlier stages of the pandemic, let the virus spread throughout their countries at a rapid rate before they were forced to implement strict measures. As a coin has two sides, head and tails, even after having so many positive effects of this decision, there are certain negative effects too. This 21-day lockdown has been implemented in a manner that has been tragic to the poorest segment of the population. There was no effective communication on how the people were supposed to negotiate or even survive this lockdown. Mr Modi in his $8 \mathrm{pm}$ speech on 24th March didn't care to address this point even once.

\section{Citizen's Reaction/Response towards their Leader's Decision}

Union Minister Ram Vilas Paswan has saluted and appreciated Prime Minister Narendra Modi's leadership during this corona virus crisis. He said that steps like asking public to clap and bang thalis and lighting diyas and flashlights helps in encouraging people and provides psychological boost during lockdown. Most of the public are in view that Mr Modi is the ideal leader to have at this time. The fight against the corona virus would certainly fail without the public's support. The success of government measures is dependent on the response of the society, which is always critical in pandemics. This calls for a political leadership that is able to convince the population to the extent of the threat, and persuade them into changing their behaviour and maintaining social order is essential. In other words, we need a leader who can gain high degree trust from the public. Mr Modi is, indeed, the most trusted politician of this generation, at least for the Hindu majority. "I am talking to you not as your PM, but as your family member," Mr Modi said addressing the public, drawing on this relationship to lure the public into accepting his extreme measures of lockdown. It is important to remember that the attempt to hide information about the corona virus by the Chinese authorities has led to this global crisis. Mr Modihas remembered this fact and wants to be transparent with the public regarding this crisis. 


\section{North Korea}

\section{Leadership Style followed in North Korea during Corona Crisis}

North Korean leader Mr. Kim Jong-un followed the Autocratic leadership style. North Korea's political system is established upon the principle of centralization. While the North Korean constitution formally guarantees protection of human rights, in practice there are severe limitations on the freedom of expression, and the government closely supervises the lives of their citizens. The constitution defines North Korea as "a dictatorship of people's democracy" under the leadership of the Workers' Party of Korea (WPK), which has been given all the powers and legal supremacy over other political parties.

Kim Jong-un practises dictatorship rule over North Korea and orders formulated by him are regarded as law. Anyone defying his orders is bound for heavy punishments. Unlike any other country the military control lies in his hands. Even news and information printed and telecasted in media lies under his control.

There are signs that the absence of corona cases in North Korea is yet another North Korean deception. After all, North Korea is formally called the Democratic People's Republic of Korea, and yet there is not a country further from being democratic. The potential proofs of corona in North Korea are significant, but because of control by Kim Jong-un over information broadcasting they keep on denying this fact.

On February 20, North Korea closed schools and colleges throughout the country, another measure that probably would not be required until and unless a contagious disease was already spreading in the country.

To avoid corona, North Korea has imposed draconian controls on border crossings, flights, and ship arrivals into North Korea and also rapidly quarantined all foreigners in North Korea. During the early stage of infection, when first North Korean patient was found corona positive, he was executed on Kim Jong-un's order and shot dead by the military to prevent any widespread of corona virus.

\section{Effectiveness of Kim Jong-un Leadership Style during Corona Crisis}

By the early-March, nearly 200 North Korean soldiers were reported to have died of symptoms closely resembling to the corona virus. Most North Korean soldiers who were infected belonged to the age group of 17-39 years of age, suggesting that perhaps most of those infected and died were belonging to the same category. North Korean soldiers don't eat very well and are not very healthy. Even if the military had gained pretty good control over this spread, the cases would likely have expanded at least 5\% per day, to jump over 20,000 cases till now. Kim Jong-un disappeared from public view for around three weeks at the beginning of February. And then, after a few days, he left Pyongyang and went to the east coast to lead artillery and missile training for several weeks; probably might be trying to avoid corona exposure in Pyongyang.

North Korea has been silently asking for help from other countries like USA and South Korea regarding corona virus aid even after it has publicly denied the existence of any cases in North Korea. 


\section{Citizen's Reaction/Response towards their Leader's Decision}

Since North Korea is ruling under dictatorship by Kim Jong-un, no one has the right to disobey his orders. Not even media and public are free to express the views regarding any law made by him. Anyone questioning or refusing to obey the orders are executed by the military law. Dong-a llbo newspaper (2020)presents thatA trade official from North Korea was shot and killed after using a public bath while he was meant to be in quarantine for a corona virus precaution. He tried to disobey the law and got punished. His execution came after North Korean leader Kim Jong-un made an order that the country would "rule by military law" against anyone who left quarantine without approval. Kim Jong-un is also likely worried about his control over the government and throne. Kim Jong-un may perceive a need to get rid of some senior elites despite how and what their families, friends and citizens are likely reacting. Kim Jong-un as a leader is more conscious about portraying a good image of his regime to the world rather than to be transparent. So there is no surprise that he has been launching missile tests, trying to divert the attention of everyone.

\section{SPAIN}

\section{Leadership Style followed in Spain during Corona Crisis}

Spain Prime Minister Mr. Pedro Sánchez followed the Laissez-faire Leadership Style. Spain now has the world's second-highest count of deaths due to corona virus. With 3,434 deaths due to corona virus, Spain has now surpassed China's total death count of 3,285. But Italy still has the most deaths count in the world with 6,820 deaths. Infection in Spain also jumped with a rise of $20 \%$ to 47,610 .

Every day at $11.30 \mathrm{am}$, the Spanish Health Ministry gives an update on the status of the corona virus outbreak in Spain. But its report on the latest figures of deaths, cases and hospitalizations does not show a true and transparent picture of the crisis. While Spain's government has announced a $€ 200$ billion euro ( $\$ 216$ billion) aid package to reduce the impact of the virus but the country is asking for more help from other countries. Prime Minister Pedro Sanchez has suggested the EU 27 to issue "corona bonds," which would share the financial burden caused by corona crisis across all member states.

But the more careful northern countries, including the Netherlands and Germany, opposed the move stating its southern neighbours could then exploit the crisis to push previous demands for Eurozone members to pool public debt. Alex Ward (March 20, 2020) On 14th March, Begoña Gómez, the wife of the prime minister was tested positive for corona virus. That news came after two government ministers were also tested positive for the disease. So as a precaution, Pedro Sánchez did his best to maintain distance from others as he works and conducts press conferences over a video link. Even Semana Santa (Holy Week), one of the country's most worshipped traditions and religious ceremonies had to be cancelled for the first time since 1933. Ward (2020), the central government had no choice left but to take more drastic measures. Spain declared a state of emergency, giving the central government a complete authority to override any decisions made by Spain's 17 autonomous regions. Pedro Sánchez took an even bigger step by imposing a 15-day complete lockdown of the entire nation. Ward (2020), to enforce these rules, police and drones roam the streets to rebuke and fine anyone caught wandering outside. Authorities have also set up about 30,000 roadblocks around the streets so that no one can secretly drive to another location. 


\section{Effectiveness of Pedro Sánchez's Leadership Style during Corona Crisis}

The main issue is that Spain's long-standing political, economic and historical problems are making a rational response very difficult. In some countries, this corona pandemic has pushed political rivalries to one side but not in Spain. Spain is the worst hit country by the corona virus outbreak, with more than 100,000 confirmed cases and over 9,000 dead.

The government's official slogan is "United, we will stop this virus". But, as the death count rises and Pedro uses emergency powers to issue economic diktats, the politics of clash has returned with a vengeance. Ward (2020), Pedro Sánchez, just week after forming a minority government, likely didn't want to risk his fragile hold on power by banning large gatherings during initial stage of corona crisis. Instead, he allowed public in huge numbers to attend soccer games, he as well as permitted a 120,000-strong feminist rally in Madrid to proceed when corona virus spreading was in initial stage. Ward (2020), the health care system was not prepared for this corona crisis. Even after a month this corona pandemic hit Spain, they weren't able to do a PCR [a diagnostic test] for corona virus without asking for authorization. They could order a PCR for a common flu, but not for the corona virus.

Ward (2020), even till date, reputed hospitals, including one in Madrid, can't process more than 400 tests a day. According to the reports of Spanish Health Ministry, about $14 \%$ of those who have been tested positive are medical workers. Spanish public gather in their respective balconies at 8 p.m. daily to applaud and salute the country's health and security services. The government claims its steps are having a positive impact in reducing the daily rise in confirmed cases in percentage terms and the numbers of new patients to intensive care wards. It has also authorised more than $€ 4$ billion funds to fight the disease. On the Madrid metro and at bus and railway stations, police distributed face masks to the commuters as part of a national strategy.

\section{Citizen's Reaction/Response towards their Leader's Decision}

Ward (2020), since country has undergone lockdown, police and drones are on continuous patrolling to keep the public at home. People have to put up an uneasy and rare silence. Public believes that the lack of foresight and planning of Pedro Sánchez doomed Spain from the beginning of this corona crisis. Instead of being united and fighting together against this corona virus pandemic Spain politicians were busy in rising fingers on opposing party. Citizens surely didn't like it when the main priority was health emergency. When Spanish public gathered in their balconies at 8 p.m. daily to applaud the country's health and security services, some people have also banged pots and pans in protest against the government. Since Spain was also suffering from declining economy the government lifted some of the restrictions during lockdown on $27^{\text {th }}$ March and allowed some businesses whose employees cannot work remotely to reopen. People in manufacturing, construction and some other services were allowed to return to work but must stick to strict safety guidelines. Public had mixed reactions regarding Pedro Sánchez's leadership. Where some people were unhappy and opposing his decisions on the other side some were appreciating his leadership. 


\section{JAPAN}

\section{Leadership Style followed in Japan during Corona Crisis}

Japan Prime Minister Shinzo Abe following the Cooperative leadership style. Japan's very first case of Corona virus was a Chinese national who'd travelled to Wuhan, the city in Hubei province, China, where the virus first came out and returned to Japan on January 6. After few days approx. two weeks later, Japan confirmed its first case of an individual who had not travelled to Wuhan, a taxi driver in Tokyo who had lately driven a Wuhan tour group.

Watanabe (2020) According to the World Health Organization (WHO), Japan had 814 cases as of March 17. Even taking into account the 712 cases from the cruise ship Diamond Princess, this was lodged at the port of Yokohama for more than three weeks as the virus spread through its passengers and crew.

Japan had not conducted aggressive testing people whereas countries such as South Korea and Italy, they had aggressively tested people of their country for the corona virus The Japanese prime minister and Cabinet Office increased their power to make policy as a result of administrative reforms since the 1990s, while the power of bureaucrats and MPs has been decreased to some range.

Japan's policy towards the corona virus seems to be centred on discussions at expert meetings under the jurisdiction of the Ministry of Health, Labour and Welfare (MHLW). Although the office of Prime Minister Shinzo Abe played important role in making decisions to stop the spread of the corona virus by convening several meetings, those decisions were based on the MHLW's expert policy recommendations.

Margolis (2020) Abe's government is going outright anti the WHO's recommendation to "test, test, test,", based on the recommendation of their panel of bureaucrats and infectious disease experts, their policy and attention is to focus on providing medical attention to those who are severely ill in order to prevent the nation's health care infrastructure from becoming overwhelmed, and to do extensive contact tracing to identify infection clusters. The health ministry and doctors are asking individuals with mild symptoms to stay at home so that they do not pass on the disease.

The Japanese National Institute of Infectious Diseases has said that the strict testing criteria are in place to preserve limited medical resources for those who are in need of urgent care. "Just because you have capacity, it doesn't mean that we need to use that capacity fully. It isn't necessary to carry out tests on people who are simply worried" health ministry official Yasuyuki Sahara said to the press.

\section{Effectiveness of PM Shinzo Abe's Leadership Style during Corona Crisis}

The Japanese Government is taking various measures to control this virus. The reason behind Japan is having less rate of infections is not acting more aggressively, but simply earlier, before sustained community spread takes its place. Japan began testing individuals with corona virus symptoms and not only those having travel history to Hubei province with the help of local governments around February 12. The government then developed a specialized team of public health and medical experts to identify and isolate infection groups. Whenever a hospital confirms a new case, the government send a team of medical and data experts to cooperate 
with local governments to locate and test anyone who has been in contact with the infected person.

Various other measures taken by PM Shinzo Abe also helped the Japanese economy to control this corona virus. Such as one of the Japan's corona virus policy has been to build a firewall against the influx of cases from overseas.

But when number of cases failed to reduce through February Shinzo Abe also induced to close all schools and request that community gatherings should be suspended for a while now. Japan was hit by a wave of closures to tourist attractions, sporting events, concerts, and festivals. The governor of Hokkaido proclaimed a state of emergency beginning on February 28 and asked the citizens to stay indoors.

Booker (2020) PM Shinzo Abe also announced plans to give incentives of 100,000 yen (\$930), to each of Japan's 120 million citizens to reduce the economic hardship of the weak Japanese economy. Booker (2020), Shinzo Abe wanted that Japanese residents should limit their contact with others by up to $80 \%$ so that the number of emerging cases can be completely reduced to nil. By following all these measures Japan has become the least affected economy among the developed countries.

\section{Citizen's Reaction/Response towards their Leader's Decision}

Fritz (2020), Japan has not shown the massive outbreak of the corona virus that has led to shut downs most of Europe and North America. Although government is doing good for the people so the peoples in Japan are less worried about the corona virus. Fritz (2020) reported that corona virus concerns weren't on the mind of the many people in Japan they are enjoying Japan's famous cherry blossoms this past weekend. Thousands of people sat under the pink grandiosity in parks, eating their favourite foods, drinking beer and enjoying clicking selfies with the budding blossoms "Hanami, the flower show, is the most important event of the year for us Japanese," said an employee at Ueno Park in Tokyo.

Fritz (2020) People obey the instructions given by their government on how to stop and prevent from corona virus as a result of which sales of face masks skyrocketed. Masks have been rationed, and people stand patiently in line waiting for shops to open. Other shops sell strips of fabric and coffee filters, along with instructions on how one can make a DIY face mask of their own. The Japanese people understood that a person can be infected without showing symptoms. Japanese people played an important role in slowing down the infection cases in Japan. As the corona virus cases came under the control, Shinzo Abe refrained from declaring a national state of emergency. Since then, the Japanese people have slowly been returning to their everyday lives. Tutoring schools are opened, with the children sitting at a distance from each other in well-ventilated rooms. Amusement parks have reopened, but if someone is running a fever then they are asked to stay away. These instructions by the Shinzo government are welcomed and obeyed by the citizens of Japan.

\section{United States of America (USA)}

\section{Leadership Style followed in USA during Corona Crisis}

Donald Trump followed the Autocratic leadership style. USA was ignorant enough and could not see the consequences clearly enough. Never in the history of mankind has New York City ever come to a halt but not only did this virus stop the New York City but also the trade and 
commerce of the entire continent. As of January $30^{\text {th }} 2020$, a total of 9,967 cases had been reported in almost 21 countries, including the first case of USA reported back on January 20, 2020. It was a 35 year old man with a travel history to Wuhan where he had gone to visit his family members and returned to Washington on January 15th, 2020.

Beginning with the creation of the White House Corona virus Task Force on January 29, and the declaration of a public health emergency on January 31, the federal government began to put in motion the executive, legal, and regulatory pandemic response procedures already on the books. It also banned foreign nationals who had travelled in mainland China from entering the country.

Even though the economic advisor to the white house Larry Kudlow, reiterated that there is a big threat to the superpower, if not shut down completely, yet Mr President underestimated the importance to US security of defeating the corona virus pandemic.

The policy adopted by the hegemony was "America first" and ironically enough, America has topped the list for having maximum number of COVID-19 cases. Nevertheless, for at least two weeks after the problem became clear, alternative paths to testing were either neglected or stymied by existing regulations. Indeed, although the Emergency Use Authorizations required by the declaration of a public health emergency were meant to facilitate rapid testing, it soon became clear that their required procedures were actually significantly retarding the development of effective testing at scale.

The fourth phase, dating from President Trump's nationally televised address on March 11 and his March 13 declaration of a national emergency, finally saw the federal government fully engage in its efforts to hasten mass testing, improve the availability of medical supplies, and encourage all Americans to radically alter their behaviour in order to arrest the spread of the virus.

Further travel restrictions were placed on foreign nationals who had travelled in continental Europe, and then in the United Kingdom and Ireland. Various emergency powers, including the Defence Production Act, were activated and then later employed. Commercial tests were approved quickly and mass testing finally became a reality — which, in turn, helped reveal the considerably advanced spread in the U.S.

\section{Effectiveness of Donald Trump's leadership during Corona crisis}

US have the highest number of Covid-19 cases, and have surpassed China and Italy in February. It seems that the situation is not much under control. The President announced an economic assistance package to help support business and workers who have been adversely affected, he also asked the Congress to include funding for this program by additional 50 billion dollars.

This action provides 200 billion dollars liquidity additional to the economy. Testing and treatment without co-payment can come out to be a great health plan. 2.5 billion Funding was granted to support the vaccine development, which was reported on February 24th 2020.

President Trump announces formation of White House Corona virus Task Force that began meeting January 27, led by HHS Secretary Azar and coordinated through National Security Council; statement also asserts that National Bio-defence Strategy, signed in 2018, will accelerate response (Statements \& Releases White Hose, 2020). 
February 24, 2020, White House - Trump's administration sends letter to Congress requesting $\$ 2.5$ billion in supplemental funding to support vaccine development, other virus responses.

March 6, 2020, White House - President Trump signs into law the Corona virus Preparedness and Response Supplemental Appropriations Act of 2020, which includes a title to help facilitate emergency tele-health services and provides $\$ 8.3$ billion in emergency funding to support development of vaccines and treatment, grants for state and local governments, preparedness activities for U.S. government facilities, and humanitarian foreign assistance.

March 11, 2020, White House issues memorandum indicating that HHS Secretary will use authority pursuant to section 319F-3 of the Public Health Service Act and Section 564 of the Food, Drug, and Cosmetic Act to facilitate emergency use of respirators; Secretary of Labour will also consider steps to increase the availability of respirators.

March 18, 2020, White House - Executive Order 13909: President Trump invokes the Defence Production Act of 1950, enabling the federal government to direct and allocate the production of protective equipment and medical supplies.

March 27, 2020, White House - President Trump signs the CARES Act into law. The most significant provisions address the economic fallout of pandemic, but Title III includes numerous provisions relating to testing, medical supply chains, drug review, tele-health, and support for healthcare.

The fourth phase and declaration of National emergency- at this point US finally saw the federal government fully engaged in its efforts by mass testing, improving health care facilities i.e. medical supplies and encouraging all the citizens to radically alter their behaviour in order to arrest the spread of virus.

\section{Citizen's Reaction/Response towards their Leader's Decision}

Public opinion has gone through four distinct phases. Early on, when the threat seemed distant, the president enjoyed a solid edge in his handling of the issue. As late as the end of February, when the first U.S. death from COVID-19 was officially recorded, he enjoyed a net rating of +9.2 percentage points. But as public awareness swelled in the next two weeks, the public mood quickly shifted.

By the morning of March 13, Mr Trump's net rating had fallen to -5.6. Later that day, he declared a national emergency. This move helped to shift public sentiment back in his favour. It peaked on March 25 at +3.5 percentage points. But during the ensuing three weeks, this trend reversed once more. As of April 17, the president's net approval had fallen to -1.6.

Based on these finding, in sum, the American people are backing an increasingly robust response to the COVID-19 epidemic, even when it limits their customary liberties, they expect this restrictive regime to continue for at least another few months, and they seem prepared to tolerate it-for how long, nobody really knows.

The very initial response of the public was that of fear. There was a huge outrage regarding the buying of essential commodities. People were seen creating chaos in supermarkets; they were flooded by huge crowds. Unavailability of certain essentials created even more panic. 
Later, the public started to realise the depth of the situation and finally started to co-operate in majority of places, but till date there are anti-lockdown protests in certain states where people are protesting against economic hardships and infringements of civil liberties.

\section{CHINA}

\section{Leadership style followed in China during Corona Crisis}

$\mathrm{Xi}$ Jinping followed the Autocratic leadership style. The first case in China suffering from COVID-19 can be traced back to 17th November 2019.

By December 20, the total number of confirmed cases had reached 60 . The virus is generally thought to have jumped to humans from wild animals, possibly a bat. According to WHO Website the first confirmed COVID-19 case in China was on Dec 8. The first death was reported on 9th January 2020, confirmed by Health Commission.

The Ash Center sat down with Tony Saich, Daewoo Professor of International Affairs at Harvard Kennedy School and Center Director, for a conversation about the impact of China's COVID-19 response on the country's leadership (The Harvard Gazzette, 2020). Xi Jinping, the President of China is known worldwide for his harsh "Autocratic or Authoritarian" leadership style. An autocratic leader gives orders which must be obeyed by subordinates and simply tells the group the immediate action to be taken. Such a leader has full control over the team leaving low autonomy within the group.

China president Xi Jinping has demonstrated a distinctive leadership style and established his personal dominance by setting up a number of small leading groups, reducing the decision making authority of his colleagues. He has made himself a populist leader by using the whole party state propaganda machine to promote his personality. China's leader is using the country's success - and the criticism against it — to urge the party and the people to weather tough days ahead (The New York Times, 2020).

As soon as the initial cases were spotted in Wuhan, the Epicentre of COVID-19, within 7 days of it China successfully managed to sequence the DNA of the virus which usually takes months or maybe years like in cases of Ebola, HIV, H1N1, etc. This helped China in developing sufficient testing kits thus they performed testing on a huge scale. The president had full control over the medical department, security department, and the media, all collectively helped in transmitting correct information to the citizen about the pandemic. The power concentration and a distinct personal leadership has helped $\mathrm{Xi}$ push long-delayed reforms.

\section{Effectiveness of Xi Jinping's leadership during Corona Crisis}

Autocratic leadership style is being followed by many other popular leaders around the world however, in the matter of its effectiveness in controlling the pandemic like this one, China tops the list. The President tried to minimise the negatives of this leadership style to enhance the co-ordination and maximized the positives of this leadership style wherein, they successfully controlled the pandemic in shortest period of time, every single agency and organisations worked as a single unit under the influence of their leader.

They performed each task in a hierarchy where at the first step they performed COVID-19 tests on a very huge scale, they tested each and every one and isolated anyone who was even 
mere symptomatic. The testing scale was so huge that every single member of each family got tested in Wuhan, Hubei. They build a hospital for COVID-19 positive cases of 1000 beds in 10 official days which is another example of co-ordination between all the departments.

At the Central level, a new central leading group on responding to the novel corona virus pneumonia outbreak, chaired by Chinese Premier - Li Kaqiang was convened in the Central Political Bureau standing committee meeting on Jan 25, 2020.

A model was launched to tackle the situation, under this model, 16 provinces has provided one-to-one support to the cities outside Wuhan, meaning that one province will be partnered with one city.

The Chinese government's response is also reflected in the high speed construction of two hospitals in about 10 days. These new hospitals will specialise in treating thousands of novel corona virus patients. Proactive measures taken by the Chinese Government restricted this pandemic from spreading to even other parts of China like Beijing, Shanghai etc. They isolated the patients, announced lockdown in Wuhan the epicentre and restricted the flights and other transport to other states and cities.

\section{Citizen's Reaction/Response towards their Leader's Decision}

Domestically, a wave of public anger fuelled by social media, has so far targeted the local leadership in Wuhan, the capital of Hubei province. Public outrage in Wuhan has spiralled following revelations on social media that local authorities had suppressed early warnings of the outbreak. Bloggers have identified eight medical personnel who had raised an alarm about the virus in late December. Police apparently accused them of "rumour mongering" but sections of the international media see in the Mayor's observations problems arising from centralisation of power by President Xi, and the alleged inherent "inflexibility" embedded in the CPC's DNA.

Western media reports, even earlier had stammered President Xi of pursuing an authoritarian leadership approach.

The corona virus outbreak in China as indeed becomes a pandemic, particularly in view of people's unfamiliarity with this new virus and the mode of its transmission. Although the early response to the epidemic in Wuhan was questioned by the public, unified action by the whole government and society was quickly launched across the country.

Many instances of tension between the central and the local party apparatus reflect a juggling act between maintaining CCP legitimacy and need to inform the public of a health threat, left public in panic and chaos initially. People from Wuhan all over the social media shared lots of instances where the brutality and harshness of the Government agencies are witnessed where people's homes are invaded and they were forcefully taking suspects even if it was a kid. These harsh measures may be were very effective but left the public traumatized and they lived for long in the feeling of fear.

\section{Conclusion or Discussion}

There is a common belief that leadership is the key to effective organisational and social performance and success. Because of the complex nature of leadership, a specific and widely accepted definition of leadership does not exist and will never be found. However, we can 
conclude that leadership is the ability to lead a group of people in achieving a common goal. This is done by people applying their leadership qualities. In response to coronavirus outbreaks and future challenges, the coronavirus puts extraordinary demands on leaders in the pandemic business and beyond. This pandemic situation seems to be importunate for the leaders all over the globe.

Prime Minister of India, Shri Narendra Modi, has been regularly interacting with Indians since the democratic leadership style and this has led to publicly praising and supporting Modi's leadership.

North Korean leader Kim Jong-un has adopted a totalitarian leadership style since Kim Jongun ruled during the North Korean dictatorship, no one had the right to defy his orders, his leadership style was unaffected and people had to follow his decision, and his leadership had no public support.

Spain PM Pedro Sánchez following Laissez-faire leadership style the main problem is Spain's longstanding political, economic and historical problems make rational response difficult. People have different reactions when they praise some of the actions taken by their leaders. On the other hand, some have criticized the government.

Japanese Prime Minister Shinzo Abe is adopting a cooperative leadership style. The Japanese government is taking several steps to control the virus. People are cooperating fully and following the orders of its leader. People have complete confidence in their leader, so they don't have to worry too much about this epidemic.

The authoritarian leadership style USA has been very ignorant since Donald Trump and apparently has not seen enough results. The president announced a financial aid package to help trade, and urged Congress to include funding for the program, which would negatively impact workers. The public had a mixed reaction to their leader's decision and were in full support of their leader. People start to grow fingers and mischief because of lack of food. The media also began to question Trump about his leadership.

Following Xi Jinping's Autocratic leadership style in China, the Chinese leadership has ordered restraint on Wuhan, although the most effective leadership has shown positive results, but the people are not happy with the methods used. Those who tried to raise their voice on social media or in real life were punished by the armed forces at the behest of Xi Jinping.

Leadership is an important success factor in times of change and even more important in times of crisis. It covers all the functions necessary to move the company to the desired future state through the crisis. The corona virus COVID-19 pandemic is the global health crisis of our time and the biggest challenge before us. Countries have done their part to slow down the spread of the virus and to isolate patients, to cancel travel, to stop citizens, to stop meetings, and to prevent a complete lockdown in most countries.

\section{Policy implications}

This research would encourage the Academicians, researchers, management students, corporate managers and employees etc. to understand the impact of different leadership styles followed by the leaders to control any devastating situation that could shatter the economy of any nation. This research would help to develop the proper understanding of the different 
leadership styles and also its implementation for determining the effectiveness of the different leadership styles in handling the uncontrollable situation.

\section{References}

Arnold, H. and Herman, B. L. (2009).eds, Managing Crises: Responses to Large-Scale Emergencies, first edition, Washington, DC: CQ Press, 2009.

Babu, V. (2011), "Divergent leadership styles practiced by Global managers in India” Indian journal of industrial relations, 46(3): 478-490.

Booker, B. (April 16, 2020).Japan Declares Nationwide State of Emergency As Corona virusSpreads.https://www.npr.org/sections/coronavirus-live- updates/2020/04/16/835925031/ japans-declares-nationwide-state-of-emergency-as-corona virus-spreads

Bostok, B. (March26, 2020). North Korea is secretly asking for corona virus aid from other countries while publicly denying that it has any cases. https://www.businessinsider.in/science/news/northkorea-is-secretly-asking-for-corona virus-aid-from-other-countries-while-publicly-denying-that-ithasanycases/articleshow/74829622.cms?utm_source=contentofinterest\&utm_medium $=$ text\&ut m_campaign $=$ cppst

Dong-allbo newspaper, (Feb 13, 2020, para.1). Kim Jong-un executed North Korea official who used public bath while in corona virus quarantine. https://nationalpost.com/news/kim-jong-unexecutes-north-korea-official-who-used-public-bath-while-in-corona virus-quarantine-reports

Elance and Aggarwal (1975). "Leadership behaviour" Delegation of authority Lok Udyog, 6: 9-20.

Fritz, M. (March 25, 2020). Corona virus: How Japan keeps COVID-19 under control. https://www.dw.com/en/corona virus-how-japan-keeps-covid-19-under-control/a-52907069

Ganta, V. C. and Manukonda, J. K. (2014). Leadership During Change and Uncertainty In Organizations. International Journal of Organizational Behaviour \& Management Perspectives, 3(3): 1183

Gemma, D. A. and Aaron, D. S. (2020). "Leadership in a crisis: Responding to the coronavirus outbreak and future challenges". Global Editorial Services, McKinsey \& Company.

Goleman, D. (2000). 'Leadership that gets results', Harvard Business Review.

Grint, K. (2007). What is Leadership? from Hydra to Hybrid. Working paper, Said Business School and Templeton College, Oxford University.

Hao, M. J.andYazdanifard, R. (2015). "How Effective Leadership can Facilitate Change in Organizations through Improvement and Innovation" Global Journal of Management and Business Research: A Administration and Management, 15(9). Version 1.0 Year 2015, Online ISSN: 2249-4588 \& Print ISSN: 0975-5853.

Margolis, E. (March 28, 2020). "This may be the tip of the iceberg”: Why Japan's corona virus crisis may be just beginning. https://www.vox.com/covid-19-corona virus-explainers/2020/3/28/211 96382/japan-corona virus-cases-covid-19-deaths-quarantine

Nahman, A. and Haim, O. (1994). "The continuity principle: A unified approach to disaster and trauma," American Journal of Community Psychology, 22(2): 273-87.

Newstrom, J. W. and Davis, K. (1993). Organizational Behavior: Human Behavior at Work. New York: McGraw-Hill.

Norman, B. N. (1970). "A study of women in Leadership position in North California" the delta-kappagamma bulletin, 36: 10-14.

Northhouse, P. G. (2004) Leadership: Theory and Practice, (3rd. ed). London: Sage Publications Ltd.

Noel, M. T. and David, O. U. (1984) "The leadership challenge: a call for the transformational leader", Sloan management review, 26(1).

Priyabhashini, A. and Krishnan, V. R. (2005), “Transformational leadership and follower's career advancement: role of Pygmalion effect" Indian journal of industrial relations, 40(4): 482-499.

Sayeed, O.B. and Shankar, M. (2009). "Emotionally intelligent leaders and Transformational leadership styles” Indian journal of industrial relations, 44(4):593-610.

\section{Border Crossing}


Singh (1978). "A study of leadership behaviour of head of senior secondary school in Haryana and its correlates" Ph.D. dissertation, Kurukshetra University.

U.S. Army. (1983). Military Leadership. Field Manual 22-100. Washington, DC: U.S. Government Printing Office.

Ward, A. (March 20,2020). How Spain's corona virus outbreak got so bad so fast - and how Spaniards are trying to cope. https://www.vox.com/2020/3/20/21183315/corona virus-spain-outbreakcases-tests

Watanabe, H. R. (March 18, 2020). Corona virus in Japan: why is the infection rate relatively low? https:// theconversation.com/corona virus-in-japan-why-is-the-infection-rate-relatively-low-13364 8

https:/ thediplomat.com/2020/03/japan-takes-additional-measures-to-fight-corona virus-outbreak/ https:// fortune.com/2020/03/23/presidential-crisis-management-trump-corona virus/

https://www.who.int/health-topics/coronavirus\#tab=tab_1

https://news.harvard.edu/gazette/story/newsplus/chinas-leadership-during-the-covid-19-outbreak/ https://www.nytimes.com/2020/05/20/world/asia/coronavirus-china-xi-jinping.html

https://www.whitehouse.gov/briefings-statements/statement-press-secretary-regarding-presidentscoronavirus-task-force/

https://www.brookings.edu/research/the-federal-governments-coronavirus-actions-and-failurestimeline-and-themes/ 